\title{
SCALE EFFICIENCY OF FARMS WITH DIFFERENT SYSTEMS OF REARING PIGS
}

Elzbieta Jadwiga Szymanska ${ }^{1}$, economist/ PhD, Associate Professor

${ }^{1}$ Warsaw University of Life Sciences - SGGW

\begin{abstract}
The efficiency of pig farms largely depends on the scale of production. Based on data from 66 farms, the models for different effects of scale were developed. They were differentiated in the field of open and closed rearing cycle. For this purpose, the DEA method, which enables to determine the effectiveness of a multidimensional system was used. Farms with fixed effects of scale prevailed in the group with open rearing cycle. They were characterized by the lowest share of their feed in the feeding of pigs and a small percentage of leased farmland. Due to the optimal scale of production to obtain, the owners of these farms achieved the highest income. Farms with increasing scale effects accounted for the largest share in the group with a closed cycle farming. They stand out the fewest resources and factors of production and the smallest scale of production. At the same time, these farms achieved the lowest economic results. A different situation occurred in farms with diminishing effects of scale. These farms were characterized by the world's greatest factors of production, the largest scale of production and the largest share of the cost of feed in the cost of production.
\end{abstract}

Key words: scale of production, efficiency, pig farms, rearing cycle.

JEL code: D24, Q12

\section{Introduction}

Pork production has great significance in the total output of meat production for many countries in the world. In fresh and processed condition, it is one of the most favourable products in the foreign market. Its advantages over other livestock products are numerous because of the quality, economical production and possibility for fully industrialised technology, which makes the pig production sector to be very important for the slaughterhouses and meat industry (Petrovska 2011, p. 1).

Pig farming is an important part of Polish agricultural activity, too. Sales of live pigs in 2015 constituted $11.0 \%$ of global agricultural production and $13.3 \%$ of commercial agricultural production (Small Statistical Yearbook of the Republic of Poland 2017, p. 265). The share of pork in the overall meat consumption accounted for $55.2 \%$, and its average consumption was $41.4 \mathrm{~kg} /$ person (Meat market 2017, p. 73). According to GUS (Polish Central Statistical Office), Poland occupies the seventh position in the EU-27 in terms of the pig livestock population, and is fifteenth in the world. In 2014, the share of Polish pork accounted for $8.2 \%$ of the EU-27 and for $1.6 \%$ of the world production (Statistical Yearbook of Agriculture, 2017, p. 403, 443).

In Poland, the main problem in pig production is an excessive fragmentation of farms, and what follows, insufficiently high scale of production, which leads to limited economic effects. The dominate role in the pig farm structure play those entities that keep several pieces of this species. In 2012, their share was $45.2 \%$. The agricultural units in which there were dozen pigs accounted for approximately $1 / 5$ of the farms. A similar proportion was true for the agricultural holdings with 20 to 49 pigs. The proportion of farms keeping larger herds, numbering from 100 to 199 animal units, was $3.9 \%$. While the percentage of farms with the largest herds of pigs amounted to only $3.1 \%$, although it was gradually increasing in 2012. The structure of pig farms observed in the largest pork producers in the EU-27 showed a decidedly larger proportion of large-scale farms numbering 1.000 or more pig units.

A small stock density is a fundamental limitation of the competitiveness of Polish pig farms. Production volume reached by the majority of Polish pork producers in the frequency of farrowing and fertility of sows are much lower than those found in the Western Europe. A small scale of production in farms and a low technical effectiveness hamper the achievement of their respective 
economic results. Even the best breeders are not able to reach parity income level without a proper scale of farming, which determines the profitability of the production of live pigs. Therefore, the aim of the study was to determine the scale efficiency of production in farms with different systems of pig farming. The task of the research was to recognize the characteristics of farms with different scale production and to recommend actions to increase production efficiency.

\section{Materials and methods}

The study covered agricultural holdings in which the minimum sale of pigs accounted for $60.0 \%$ of their commercial production, and which kept 50 and more sows and/or produced at least 1000 fattening pigs per year. The principal reason for choosing these criteria was that only farms with large-scale production can compete with the biggest producers of pork in the EU. The surveyed facilities were selected in two stages. First, there were selected regions of greatest importance in pig production in Poland. Next, the Polish Regional Agricultural Advisory Centres were requested to localize farms that meet the required criteria. Eventually, the research covered 66 farms specializing in the production of live pigs, which provided the data gathered through an interview questionnaire directed in 2010.

The farm data analysis was based on the DEA method, which allows determining the efficiency in a multi-dimensional system (Parlinska, Bezat 2008, p. 122). In addition, it allows recognizing which installations have good economies of scale and what direction they should take to develop (Rusielik, Prochowicz 2007, p. 29).

To assess the economies of scale of the surveyed agricultural holdings, it was accounted for that the economies involved the value of a farm production and expenditures covered investment in the land (the number of ha of $\mathrm{AL}$ ), labour inputs (the number of full-time employed persons), the fixed capital investment (the value of fixed assets) and working capital (the costs of consumption of materials, energy and external services). These variables allowed to calculating investmentoriented technical efficiency of farms having fixed and variable economies of scale. It was assumed that for the units engaged in economic farming to minimize inputs is more important a goal than to maximize production. Then, the scale efficiency (SE) was determined. In order to determine in which area a given farm operates, whether it has an increasing or decreasing scale, the author calculated the efficiency of not increasing economies of scale (TENIRS) and it was compared with technical efficiency with varying economies of scale (TEVRS).

The data provided the basis for the development of the model farms with different economies of scale. A further distinction was made between them into open and closed cycle systems of farming. The basis for this approach provided such differences between the units as varied resources of land, labour and capital, different organization and production technology.

\section{Research results and discussion}

The scale of production is a fairly complex term, which makes it difficult to give it an unequivocal meaning. According to Samuelson and Marks (1998, p. 238) the scale production of a company is the size of investment, all production factors that are used. Whereas Wos and Tomczak claim $(1979$, p. 191) that the term refers primarily to the volume of production, although it is also indirectly related with the resources and inputs of production factors, which stems from the obvious relationship between the production and expenditures. In turn, Kowalski's (1993, p. 19) general approach to the scale of production defines it as "the volume of a single, separable production 
process." In his opinion, the precise meaning of this concept is based on the analysis of the context.

Production at a certain scale implies some kind of organization and economics of production and the associated production efficiency (Wos, Tomczak 1979, p. 193). Increasing the scale of production entails certain benefits, known as economies of size. They result from a faster production growth in relation to the consumption of the factors of production. The concept of economies of size means that the average cost per unit of production decreases as the size of the farm increases. The economies can occur because the farmer is able to spread more production over the same level of fixed expenses. Or, economies of size can occur when a farm is able to obtain volume discounts for inputs such as seed or fertilizer (Duffy 2009). These benefits rise as the scale of production increases, but not without limitation and not always in direct proportion to the increasing scale of production. If the volume of production increases at the same rate as the input of production factors, then the economies of scale stay constant. On the other hand, when the volume of production grows faster than the input of production factors, then the economies of scale are increasing. The converse indicates to the decreasing economies of scale. The economies of scale occur, however, only up to a certain level of production. Once a certain threshold has been crossed, there can be observed an increase in the unit cost of production and the so called reverse economies of scale, also referred to as diseconomies of scale. The reverse economies of scale take place when an increase in the consumption of factors of production does not result in a corresponding increase in production (Kowalczyk 1998, p. 241).

The major benefits of increased scale of production in the farm are:

- reduction of unit production costs due to lower fixed cost imposed on the production unit;

- possible use of new production technologies, which are uneconomical on a small scale;

- labour productivity growth owing to simplified means of keeping and handling larger herds and to fewer preparatory and terminating activities;

- upgrading skills of persons engaged in production;

- introduction of modern management techniques and control of production processes;

- improving the quality of production, and hence the competitive strength of production;

- obtaining favourable selling prices and lower purchase prices of means of production;

- making the best of technical progress, mechanization of production, rationalization of work, new manufacturing technologies etc.

- The increase of the production scale may entail some adverse effects. These include:

- the growth of natural and market risks due to the limitation of offer associated with a higher scale;

- increased risk of various diseases;

- the increase in environmental pollution.

The question about optimal farm size has a long history in agricultural economics. Numerous authors have been analysing the relationship between farm size and efficiency (Fandel 2002; Bielik, Rajcaniova 2004; Hughes 2000; Madau 2010; Rasmessen 2011). Many research works have concerned the scale efficiency in pig farms too (Petrovska 2011; Asmild, Hougaard 2006; Umeh, Ogbanje and Adejo 2015). More detailed analyses were carried out in this study. The scale efficiency of production was determined in farms with different systems of pig farming. The analysed farms were divided into two groups with a closed and open rearing cycle. The closed cycle is considered to hold all technological groups of pigs and the final product are porkers. Renovation 
of the herd on these farms are made on the basis of own or purchased animals. Open cycle is characterized by a specialization in one or two stages of the production cycle, regardless of the origin of the material for production.

42 farms out of the surveyed group were engaged in closed-cycle pig farming. All technological groups of pigs were kept there, the final product being fattening pigs. The statistical description of these farms is presented in Table 1.

The scale of production and selected outlays in closed-cycle farms

Table 1

\begin{tabular}{|l|c|c|c|c|}
\hline \multicolumn{1}{|c|}{ Variables } & Average & Min. & Max. & Standard deviation \\
\hline Live pigs production in tonnes & 866.5 & 329.1 & 4152.3 & 630.5 \\
\hline Utilized Agricultural Are in ha & 99.0 & 8.3 & 466.0 & 100.8 \\
\hline Number of persons employed on a full-time & 4.0 & 1.1 & 21.0 & 3.4 \\
\hline Fixed capital in thous. PLN & 1306.2 & 501.9 & 4193.3 & 691.7 \\
\hline Working capital in thous. PLN & 566.8 & 224.9 & 3390.3 & 497.9 \\
\hline
\end{tabular}

Of all closed-cycle farms, only $28.6 \%$ had an optimal scale of production, namely the one that allowed for the most efficient use of the investments. The growing nature of the scale marked $40.5 \%$ of farms. This means that the production of these units increased faster than the amount of factors of production. In contrast, $30.9 \%$ of agricultural holdings from the study group were characterised by a decreasing scale. In these units, production was increasing more slowly as against the expenditure incurred.

Closed-cycle pig farms with different economies of scale differed in terms of the index levels of available resources, organization of production and results (Table 2). In farms with constant economies of scale, an average arable land area was 58.6 ha. At the same time the owners of these farms exploited leased agricultural land to the minimum. The leased land area in this group accounted for only $14.1 \%$. Farms with constant economies of scale were also characterized by the highest pig density. On average, 100 ha of arable land accounted for 612.4 LSU of this animal species. In addition, these farms benefited from their own feed in feeding pigs to a minimal extent. The average contribution of concentrate feed of own production amounted to $36.9 \%$ Almost 2-fold greater amounts of feed were purchased. Therefore, the average share of feed costs in direct costs of pig production reached the level of $86.9 \%$. The costs of purchase of animals accounted for just $3.3 \%$. In this group of farms, a rational use of inputs made way for high economic results in the form of agricultural income at the level of PLN 223.9 thousand.

Farms with decreasing economies of scale were characterised by the largest arable land area, which averaged 196.2 ha. Leased land accounted for more than $1 / 4$ of this area. In addition, these farms had the highest labour force. An average number of full-time employed persons was 7.1, with about half of the full-time employees being hired. Their participation averaged $52.3 \%$. Agricultural holdings with decreasing economies of scale were also marked by the highest value of fixed assets (PLN 1917.9 thousand on average) and by the highest level of debt (11.2 \%). At the same time, these farms, as compared with the others, invested many of their funds, i.e. on average PLN 376.5 thousand per year. They were characterized by the largest scale of production, which averaged 376.5 tons of live pig annually. Compared with the first group of holdings, this scale was nearly three times higher and as against the units with increasing economies of scale, more than four times higher. However, due to a large area of these farms an average stocking 
density of pigs in this group was the lowest and amounted to 176.2 LSU per 100 ha of arable land. At the same time, these farms benefited to the greatest extent from their own feed in the pig feeding, which share in feed doses was $65.3 \%$. Thus, the share of costs of feed in direct costs of pig production in this group was the highest and represented $92.8 \%$. Whereas the proportion of costs incurred to purchase the animals, compared with other groups of agricultural holdings, was the lowest and averaged $1.5 \%$. These holdings were characterized, however, by the highest farm income at the level of PLN 327.7 thousand.

Selected characteristics of closed-cycle farms with different economies of scale

\begin{tabular}{|l|c|c|c|}
\hline \multirow{2}{*}{ Variables } & \multicolumn{2}{c|}{ Economies of scale: } \\
\cline { 2 - 4 } & Fixed & Growing & Decreasing \\
\hline Arable land area in ha & 58.63 & 53.60 & 196.20 \\
\hline The share of rented UAA in \% & 14.1 & 19.5 & 52.3 \\
\hline $\begin{array}{l}\text { Number of persons employed on a full- } \\
\text { time }\end{array}$ & 3.0 & 2.8 & 7.1 \\
\hline The share of wage labour inputs in \% & 24.7 & 14.8 & 52.3 \\
\hline The value of fixed assets in thous. PLN & 1182.4 & 907.7 & 1917.9 \\
\hline Debt ratio in \% & 10.2 & 7.8 & 11.2 \\
\hline The value of investments in thous. PLN & 126.2 & 88.1 & 376.6 \\
\hline $\begin{array}{l}\text { The scale of life pig production in } \\
\text { tonnes }\end{array}$ & 189.7 & 109.2 & 230.9 \\
\hline $\begin{array}{l}\text { Stocking density of Pigs per 100 ha } \\
\text { UAA }\end{array}$ & 612.4 & 297.7 & 176.2 \\
\hline The share of own fodder in feeding & 36.9 & 50.4 & 65.3 \\
\hline The share of fodder costs in \% & 86.9 & 87.9 & 92.8 \\
\hline The share of purchase animals in \% & 3.3 & 4.4 & 1.5 \\
\hline Agricultural income in thous. PLN & 322.0 & 139.9 & 327.7 \\
\hline mor's study & & & \\
\hline
\end{tabular}

Source: author's study

Farms with increasing economies of scale had the smallest average area of arable land, normally totalling 53.6 ha. The share of leased land in this group accounted for $19.5 \%$. Compared to the other farm groups, holdings with increasing economies of scale were characterized by the smallest labour force, which numbered on average 2.8 persons employed on a full-time basis. At the same time, the participation of hired workers in those farms was highly limited. The share of paid labour force there was $14.8 \%$. Agricultural holdings with increasing economies of scale were also characterized by the lowest value of fixed assets, at the level of PLN 907.7 thousand. Regardless of this, the owners of these farms invested very little, comparing with other groups. The average value of investment amounted to PLN 88.1 thousand per year. Furthermore, these farms were characterized by the lowest level of debt. The share of foreign capital in the business assets accounted for only $7.8 \%$. The scale of production in this group was the lowest. An average pig production amounted to PLN 109.2 thousand tons per year. Whereas the stocking density of pigs in farms with decreasing economies of scale accounted for 297.7 LSU per 100 ha of arable land. More than half of feed fed to pigs came from own production, but the share of feed in direct costs in this group was similar to that in agricultural holdings with constant economies of scale. The proportion 
of the costs of purchasing livestock accounted for $4.4 \%$. The level of agricultural income achieved in these farms was the lowest, averaging PLN 139.9 thousand.

An open cycle pig farming was conducted in 24 farms. It involved specialization in one or two stages of the production cycle. Most often it meant fattening of purchased piglets or weaners. The statistical description of these farms is presented in Table 3. In this group, an optimal scale of production was observed in $47.6 \%$ of agricultural holdings. Increasing economies of scale could be observed in $23.8 \%$ of the units. A different situation was observed in $28.6 \%$ of farms with decreasing economies of scale. Farms in the separate groups were highly specialized. A different situation was observed for available resources, organization of production and economic performance.

The scale of production and selected outlays in closed-cycle farms

Table 3

\begin{tabular}{|l|c|c|c|c|}
\hline \multicolumn{1}{|c|}{ Variables } & Average & Min. & Max. & Standard deviation \\
\hline Live pigs production in tons & 999.1 & 345.1 & 3373.3 & 701.6 \\
\hline Utilized Agricultural Are in ha & 63.0 & 8.0 & 201.0 & 58.0 \\
\hline Number of persons employed on a full-time & 4.0 & 1.0 & 8.0 & 2.0 \\
\hline Fixed capital in thous. PLN & 1292.9 & 453.3 & 3199.5 & 822.1 \\
\hline Working capital in thous. PLN & 1219.0 & 298.0 & 4879.3 & 1056.7 \\
\hline
\end{tabular}

Source: author's study

Farms with constant economies of scale exploited a smaller area of arable land, covering on average 54.3 ha (Table 4). They also benefited from the lease of land to a minimum extent. The share of leased land accounted for an average $13.0 \%$. Whereas an average number of full-time employed persons was 4.0 per farm. At the same time, half of the employees were agricultural contract workers. What is more, farms with constant economies of scale were marked by a lower indebtedness. The share of foreign capital in financing farming activities accounted for $27.9 \%$. In the other groups of farms, the percentage of debt was about ten per cent lower. In addition, the holdings of the first group invested most of their resources. Their value of investments averaged PLN 166.6 thousand per year. Nonetheless, the scale of production of live pigs was higher than in agricultural holdings with increasing economies of scale and lower than in farms with decreasing economies of scale.

It amounted to an average of 268.9 tons of live pigs a year. In contrast, the farms with constant economies of scale exhibited definitely the highest density of herds. Stocking density of pigs per 100 ha of arable land amounted on average to $2251.4 \mathrm{LU}$. The pig feeding resources were dominated by purchased feed. The share of the farm-produced feed was $27.4 \%$. The largest per cent of direct costs of pork production constituted the feed costs (49.9\%) but the cost of purchasing animals also had a large share, amounting to an average of $47.5 \%$. What is more, farms with constant economies of scale met the highest agricultural income. On average, their agricultural activities had a turnover of PLN 252 thousand.

In the farms with increasing economies of scale, an average arable land area was only slightly larger than that reported in the first group and covered 58.15 ha. Leased land constituted more than $1 / 4$ of this area. Additionally, these farms were characterised by lower labour force. As few as 2.0 persons were full-time employed there. Concurrently, $25.1 \%$ of these were contract workers. Farms with increasing economies of scale also stood out for the lowest value of fixed assets, 
amounting on average to PLN 799.5 thousand. The share of foreign capital in their assets value amounted to $16.8 \%$. At the same time the owners of these farms invested only PLN 42.8 thousand per year, which is more than four times less than in the other groups. The scale of production in these units was the lowest and amounted to 126.8 tons of livestock per year. Similarly, the stocking density of pigs was lower than in the other groups of farms and averaged 432.9 LSU per 100 ha of agricultural land. The share of own feeds in the pig feeding was higher by $11.7 \mathrm{pp}$ in comparison with farms with constant economies of scale. In contrast, the percentage of costs of feed and purchasing livestock was at a similar level to that of the first group. At the same time, farms with increasing economies of scale reached their lowest level of agricultural income. Compared with the income of the other groups of farms, it was more than twice lower.

Selected characteristics of open cycle farms with different economies of scale

\begin{tabular}{|l|c|c|c|}
\hline \multirow{2}{*}{ Variables } & \multicolumn{3}{c|}{ Economies of scale } \\
\cline { 2 - 4 } & Fixed & Growing & Decreasing \\
\hline Arable land area in ha & 54.34 & 58.15 & 79.81 \\
\hline The share of rented UAA in \% & 13.0 & 25.6 & 24.7 \\
\hline Number of persons employed on a full-time & 4.0 & 2.0 & 5.2 \\
\hline The share of wage labor inputs in \% & 49.3 & 25.1 & 43.8 \\
\hline The value of fixed assets in thous. PLN & 1309.3 & 799.5 & 1686.4 \\
\hline Debt ratio in \% & 27.9 & 16.8 & 13.7 \\
\hline The value of investments in thous. PLN & 166.6 & 42.8 & 162.0 \\
\hline The scale of life pig production in tonnes & 268.9 & 126.8 & 355.7 \\
\hline Stocking density of pigs per 100 ha UAA & 2251.4 & 432.9 & 818.5 \\
\hline The share of own fodder in feeding in \% & 27.4 & 39.1 & 42.0 \\
\hline The share of fodder costs in \% & 49.9 & 49.6 & 53.9 \\
\hline The share of purchase animals in \% & 47.5 & 46.7 & 43.9 \\
\hline Agricultural income in thous. PLN & 252.0 & 112.4 & 219.5 \\
\hline
\end{tabular}

Source: author's study

Agricultural holdings with decreasing economies of scale were characterised by the largest areas of arable land, which averaged 79.81 ha. Almost $1 / 4$ of these lands were leased. In addition, these holdings had the largest labour resources. On average, 5.2 persons were employed there on a fulltime basis. At the same time hired workers represented $43.8 \%$ of labour input. An average value of fixed assets was also the highest in this group as it amounted to PLN 1686.4 thousand. On the other hand, the level of indebtedness of agricultural holdings with decreasing economies of scale was the lowest compared with the other groups of farms. The debt ratio of the total assets amounted to an average of $13.7 \%$ and was more than two times lower than in the first group of farms. On the other hand, the value of investments in farms with decreasing and constant economies of scale was similar, accounting for an average of PLN 162.0 thousand. Moreover, the holdings with decreasing economies of scale were characterized by the highest scale of production, which amounted to 355.7 tons of live pigs per year. The average density of this animal species in this group of agricultural holdings was much lower than in the first group and amounted to 818.5 LU per $100 \mathrm{AL}$. These farms also largely benefited from their own feed in the pig feeding process, which share accounted for $42.0 \%$. In spite of this, the percentage of feed costs in direct costs of 
live pig production was the highest in this group and totalled $53.9 \%$. In turn, the share of costs of purchasing animals was lower by 10 percentage points. In terms of the achieved agricultural income, the position of farms with decreasing economies of scale was worse than that of holdings with constant economies of scale. On average they accrued income at the level of PLN 219.5 thousand a year.

\section{Conclusions, proposals, recommendations}

1) Based on these results, it can be stated that some pig farms in Poland reached the optimal scale of production with given resources and that their further growth does not lead to increased efficiency.

2) Farms with constant economies of scale prevailed in the group of open cycle farms. They were marked by the smallest share of their own feed in the pig feeding and by a small percentage of leased farmland. Due to an optimal scale of production, the owners of these farms obtained the highest income.

3) Farms with increasing economies of scale were most numerous in the group of closed-cycle farms. Characteristically, they had the fewest resources of production factors such as labour and capital, and the smallest scale of production. In his group of farms, few resources were invested and participation of paid labour force was minimal. At the same time these agricultural holdings had the lowest economic results. In order to make an optimal use of the investment, it is advisable to increase the scale of production in these units.

4) A different situation was observed in agricultural holdings with decreasing economies of scale, where production increased at a slower rate as against the incurred expenditures. These farms were characterized by the most significant factors of production, the largest scale of production and the largest share of feed costs in the production costs. Therefore, to improve the efficiency of these farms it is required to change their organization and production technology.

5) The data indicate that Poland has a large potential in the production of live pigs; however, in order to be able to withstand the increasing competition in the European and global markets the scale of production in a great number of domestic pig farms should be increased.

\section{Bibliography}

1. Asmild, M, Hougaard, J.L. (2006). Economic and Environmental Efficiency of Danish Pig Farms. Agricultural Economics, No 35, pp. 171-181.

2. Bielik, P., Rajcaniova, M. (2004). Scale Efficiency of Agricultural Enterprises in Slovakia. Agricultural Economics - Czech, No 50 (8), pp. 331-335.

3. Duffy, M. (2009). Economies of Size in Production Agriculture. Journal of Hunger \& Environmental Nutrition, No 4(3-4), pp. 375-392.

4. Hughes, G. (2000). Total Productivity of Emergent Farm Structures in Central and Eastern Europe. In: Banse M., Tangermann S., eds. Central and Eastern European Agriculture in an Expanding European Union. Walingford, CABI Publishing, pp. 61-87.

5. Kowalczyk, S. (1998). Firma agrobiznesu. Ekonomika skali w firmach agrobiznesu. [w:] Encyklopedia agrobiznesu, red. A. Woś (Agribusiness company. The economics of scale in agribusiness companies. In: Wos A. (eds.): Encyclopedia of Agribusiness.) Publishing house "Foundation Innovation", Warsaw.

6. Kowalski, Z. (1993). Skala a efektywnosc gospodarowania w rolnictwie (w swietle funkcji produkcji). Zagadnienia Ekonomiki Rolnej, (Scale and effectiveness of farming in agriculture in the light of production function). Issues of Agricultural Economics, No 1-2, pp. 52-61.

7. Madau, F.A. (2010). Parametric Estimation of Technical and Scale Efficiencies in Italian Citrus Farming. MPRA Paper 26818, University Library of Munich, Germany.

8. Meat Market, Condition and Orospects, No. 47/2014, Institute of Agricultural Economics and Food Economy, Agricultural Market Agency, Ministry of Agriculture and Rural Development. Warsaw.

9. Parlinska M., Bezat A. 2008: Efficiency of the Polish Wholesale Markets - Validation based on the Data Envelopment Analysis. Annals of the Polish Association of Agriculture and Agribusiness Economists, Vol. X, No. 5, s.122-124. 
10. Petrovska, M. (2011). Efficiency of Pig Farm Production in the Republic of Macedonia-Data Development Analysis approach. Swedish University of Agricultural Sciences Uppsala. https://stud.epsilon.slu.se/3749/1/petrovska_m_111229.pdf. Access: 10.12.2016.

11. Rasmussen S. (2011). Estimating the technical optimal scale of production in Danish agriculture. Food Economics - Acta Agriculturae Scandinavica, Section C, April 2011, Vol 8, Issue 1, pp. 1-19.

12. Rusielik, R., Prochowicz, J. (2007). Porownanie efektywnosci skali produkcji mleka w wybranych gospodarstwach Europy w 2005 roku. (Comparison of the efficiency of milk production scale in selected European farms in 2005.) Annals of Agricultural Sciences, Series G, T. 94, Vol. 1, pp. 29-34.

13. Samuelson, W.F., Marks S. G. (1998). Ekonomia menedzerska. (Managerial Economics), State Economic Publishing House, Warsaw.

14. Small Statistical Yearbook of the Republic of Poland, Central Statistical Office, Warsaw 2017.

15. Statistical Yearbook of Agriculture, Central Statistical Office, Warsaw 2015.

16. Umeh, J.C., Ogbanje, Ch., and Adejo, M.A. (2015). Technical Efficiency Analysis of Pig Production: A Sustainable Animal Protein Augmentation for Nigerians. Journal of Advanced Agricultural Technologies, Vol. 2, No. 1, pp. 19-24.

17. Wos, A., Tomczak, F. (1979). Ekonomika rolnictwa. Zarys teorii. (Economics of agriculture. Outline theory.), State Publishing House of Farming and Forestry, Warsaw. 